\begin{tabular}{cc}
\hline International Journal of Engineering \& Technology, $9(2)(2020) 501-508$ \\
SPC & Website: www.sciencepubco.com/index.php/IJET \\
Research paper & Technology \\
\hline
\end{tabular}

\title{
Factors affecting the continuation of contractor participation in the tender process for the construction services project at the center for policy research and development and application of technology - research and development agency ministry of public work and public housing
}

\author{
Novi Arteti ${ }^{1 *}$, Syafwandi ${ }^{1}$, Budi Susetyo ${ }^{1}$ \\ ${ }^{1}$ Mercu Buana University, Jakarta, Indonesia \\ *Corresponding author E-mail: noviarteti11@gmail.com
}

\begin{abstract}
The application of new technology as a result of research and development carried out by the Research and Development Agency of the Ministry of Public Works and Public Housing is one of the efforts for technological needs in infrastructure development. The implementation of technology implementation activities still faces many obstacles, one of which is the tender process. Project Characteristics Factors, Capability of Contractors and Application of New Technology can influence whether the contractor will continue or stop the tender process. This research is based on a sample of respondents from related parties including goods / service providers (contractors), work owners and groups of goods / services procurement units. The results of the data obtained were analyzed with the partial least-squares structural equation model (PLS-SEM). The analysis shows that the ability of the Contractor has the greatest influence on the Tender Process. This means that the contractor's resources are the main force to carry out the project so that it is not too dependent on other parties. Thus, it can be concluded that the consideration of ownership of the contractor's resources becomes a factor for the contractor to continue the tender process that he follows by making an offer. Because with its capital and equipment, the contractor will be able to offer more efficiently.
\end{abstract}

Keywords: Participate in the Tender Process; Ability of Contractor; Project Characteristic; and Implementation of New Technology.

\section{Introduction}

The Ministry of Public Works and Public Housing, since 2017 through the technical implementation unit under the Research and Development Center for Policy and Technology Application, has been implementing technology from result of research and development activities. And it is included in the scope of project construction that is need large enough resources and continuous over a relatively limited period of time. Projects are considered successful if they meet quality targets, costs and time (Susetyo and Utami, 2017).

The technology implementation activities are carried out through e procurement in accordance with Presidential Regulation of the Republic of Indonesia Number 16 of 2008 concerning Government Goods / Services Procurement.

To carry out technology implementation activities, the initial focus was on the National Tourism Strategic Areas such as Lake Toba Tourism Area, Labuan Bajo, Borobudur, Bromo and Morotai.

Based on data obtained from implementing work units from 2017 - 2019, it turns out that the contractors participating in the tender are lacking. They were initially interested in the technology implementation project being auctioned, but after registering, they did not continue the auction process by bidding. (Results of data processing from implementing units under the Center for Policy Research and Development and Application of Technology during 2017-2019).

In fact, with more and more contactors bidding, it provides an alternative for the auction committee to provide an assessment and choose the best contractor to carry out the offered project.

Based on these data, the researcher wants to examine what factors cause the contractor to only register for auctions but not proceed to bidding, especially the application of research and development technology in the Ministry of Public Works and Public Housing which is carried out by work units under the Center Policy Research and Development and Application of Technology. 


\section{Literature study}

\subsection{E-procurement}

e-procurement can be interpreted as an application for the implementation of procurement of goods/services electronically by utilizing internet-based information technology. Procurement of goods/services electronically is done by e-tendering or e-purchasing. The definition of e-procurement from various literatures has the same meaning, namely procurement of goods/services using information and electronic technology (Sutedi 2012; Andrianto 2007; Abidin 2012; Kalakota et al, 2001 in Egbu et al, 2003).

Procurement based on the use of information technology is an attempt to achieve the main principles in order to lead to perfect competition, including: there are no restrictions to access information from the Government, increase market transparency.

\subsection{The involvement of parties in e-procurement}

In accordance with Presidential Regulation of the Republic of Indonesia Number 16 Year 2018 regarding Procurement of Government Goods and Services, the parties directly involved in the e-procurement process include:

1) Budget Users: officials holding the authority to use the budget of the State Ministry/Institution/Regional Apparatus.

2) Budget User Authority: an official who obtains power from the Budget User to exercise part of the authority and responsibility for the use of the budget at the State Ministry/Institution concerned.

3) Commitment Officials: officials authorized by the Budget User/Budget User Authority to make decisions and/or take actions that can result in the expenditure of the state budget/regional expenditure budget

4) Election Working Group: human resources determined by the head of the Procurement Working Unit to manage the selection of Providers

5) Government Goods/Services Providers, hereinafter referred to as Providers, are Business Actors who provide goods/services based on contracts

\subsection{Application of new technology}

Housing is carried out by the Research and Development Agency through the Research and Development Center for Roads and Bridges, the Research and Development Center for Water Resources and the Research and Development Center for Settlements.

The scope of research and development as stipulated in the Minister of Public Works Regulation number 07/PRT/M/2012 concerning the Implementation of Research and Development covers aspects of general and technical planning, programming, construction, operation and maintenance, materials and equipment technology, and governance, supervision, and control with output in the form of applied science, applicable technology, and intellectual property.

The results or outcomes of the research and development activities are then carried out through technology transfer activities by the research and development implementation team to the stakeholders. The process of technology transfer can take the form of publication, socialization, dissemination, training and education, and the use of licenses with or without cooperation (Hendrawan, 2012).

After the technology transfer activity, the activity carried out is the application of new technology which is expected to be the final pilot so that it can be continued by other technical implementing units in mass.

\subsection{Characteristic of construction project}

In general, project characteristics greatly affect the surrounding environment. Factors that can affect project characteristics, among others:

1) Limited location and land.

2) Political risk.

3) Economic risks.

4) Impact on the public.

5) Technical approval by the authorities.

6) Sufficient funds are available.

According to Ahuja (1983), the most important characteristics of a project are: objectives, schedule, complexity, size and assignment of tasks, available resources and control and information systems.

\subsection{Hypothesis of research}

Based on the results of previous studies, it can be understood that there is a correlation between the factors of several variables on the overall tender process. The influencing factors can vary according to the context and relevance of each research.

Considering the results of the previous research and paying attention to the theories which form the basis of this research thinking, the formulation of the research hypothesis is as follows:

H1: There is a significant influence between the contractor's ability to the contractor not to proceed with the tender process.

H0: There is no significant effect between the ability of the contractor to the contractor not continuing the tender process.

$\mathrm{H} 2$ : There is a significant influence between the characteristics of the project on the contractor not continuing the tender process.

H0: There is no significant effect between the characteristics of the project on the contractor not continuing the tender process.

$\mathrm{H} 3$ : There is a significant influence between the application of new technology to the contractor not continuing the tender process.

H0: There is no significant effect between the application of new technology to the contractor not continuing the tender process.

H4: There is a significant influence between the ability of the contractor, the characteristics of the project and the application of new technology to the contractor not continuing the tender process.

H0: There is no significant effect between the ability of the contractor, the characteristics of the project and the application of new technology to the contractor not continuing the tender process. 


\section{Research methodology}

Research on the analysis of factors that prevented the contractor from continuing the tender process when viewed based on the manner and measurement and analysis of the data, this study was classified as a survey research, because it used questionnaires as its main source, and also as quantitative research.

\subsection{Research type}

In this study, the analysis was conducted by describing the results of the analysis of the description of the respondents according to what was filled in the questionnaire, which can be categorized statistically based on the background of the respondent, such as: age of respondent, gender, work experience and years of service and last education.

\subsection{Research variable}

The independent variables in this study are the ability of the contractor, the characteristics of the project, and that can make the stakeholders decide not to proceed with the tender process.

Independent variables $(\mathrm{X})$ in this study are as follows:

1) Ability of the contractor (X1).

2) The application of new technology (X2).

3) The characteristics of the project (X3).

The dependent variable determined in this study is the tender process, which consists of the following parameters:

1) Announcement Stage (Y1).

2) Bidding Stage $(\mathrm{Y} 2)$.

3) Evaluation Stage (Y3).

From all the variables defined in this study, then the pattern of relationships between independent variables and the dependent variable is arranged in accordance with the rules based on the theory and previous studies in the form of Structural Equation Modeling (SEM).

Before carrying out data collection through questionnaires, this study tested the research instruments to convince researchers that the instruments used in this study were scientifically and academically used and accountable. The testing of the instrument is as follows:

1) Validity test: used to test whether the questionnaire prepared and will be used in this study is statistically acceptable or valid.

2) Reliability tests: indices that show the extent to which the gauges can be trusted or relied upon.

\subsection{Research population and sample}

The population determined as subjects in this study includes the stakeholders in the contractor who have registered in a new technology implementation project implemented by the Center for Policy Research and Development and Application Technology and is expected to have a direct impact on decision making in the tender process, which is focused on the contractor main who have already registered on the project.

To determine the population of this study, the authors use data from parties involved in technology implementation projects, namely the Service Provider and the owner handling the procurement activities. The data obtained by the author as many as 100 service providers and 28 owners who handle procurement activities.

Sampling was carried out proportional stratified techniques in accordance with the distribution of the population of each stakeholder that was recorded using the Slovin formula to determine the number of research samples needed, with a confidence level of $95 \%$ or a margin of error of $5 \%$.

\subsection{Data analysis technique}

This research uses Structural Equation Modeling - Partial Least Square (PLS-SEM) as an analysis aid. The software applied in this study uses SmartPLS 3.0.

Project characteristics, the ability of contractors, the application of new technologies and the tender process, are treated as latent variables with each indicator.

In this study structural modeling with a reflective construct is used, so that it takes 3 ways of measurement are Convergent Validity, Discriminant Validity and Composite Reliability. This step is an Evaluation of the Measurement Model (Outer Model).

The next step is to evaluate the structural model (Inner Model). The structural model is evaluated using R-square for the dependent construct, Stone-Geisser Q-Square test for predictive relevance and $t$ test as well as the significance of the coefficient of structural path parameters. Inner models (inner relations, structural models, or substantive theory) describe the relationship between latent variables based on substantive theory. Changes in the value of R-Square can be used to assess the substantive influence of certain independent latent variables on the dependent latent variable.

The final step is to test the hypothesis. Hypothesis testing is used to see the direction of the relationship between the independent variable and the dependent variable. Testing in this study was conducted by path analysis of the planned model.

Hypothesis testing in this study is assisted with SmartPLS 3.0 software which simultaneously tests complex structural models, so that the path analysis results are obtained in one regression analysis. The correlation results between constructs are measured by looking at the path coefficient and the level of significance.

\subsection{Research framework}

In this study, the author analyze the variable capabilities of the contractor, the characteristics of the project and the application of new technologies that cause the contractor to not continue the bidding process on the application of new technology resulting from research and development using quantitative research and in non-experimental types arranged as in design research and thinking framework below: 


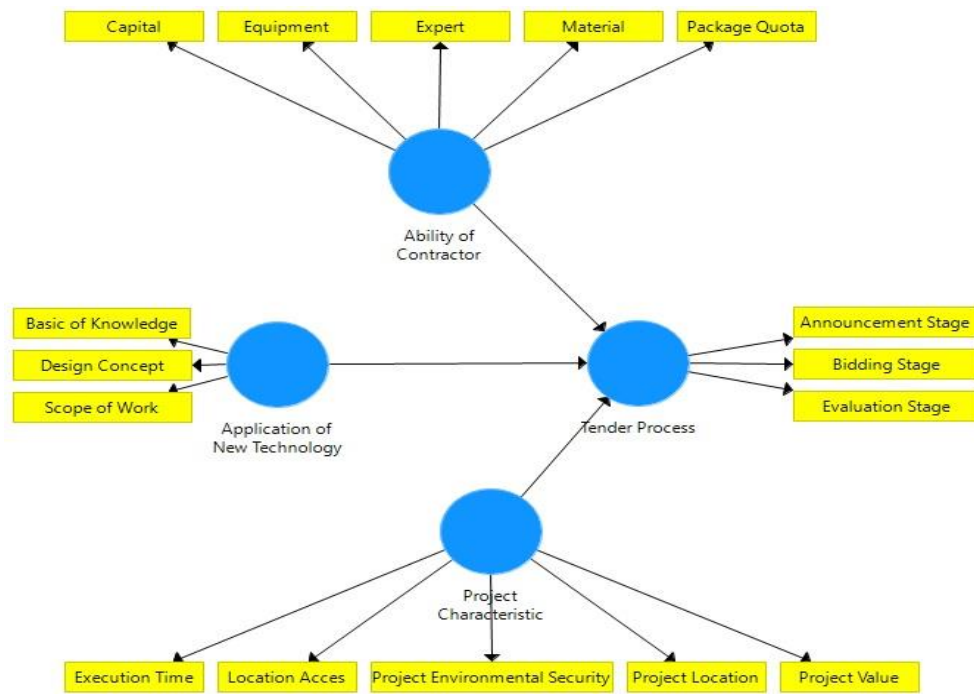

Fig. 1: Design Research and Thinking Framework.

\section{Finding and discussion}

\subsection{Description of research object}

The number of respondents who answered the questionnaire was 102 respondents out of 128 questionnaires distributed. From all respondents in this research, the respondents of 31- 40 years old are 43 or $42 \%$ and the respondents of 41 - 50 years old are 34 or $33 \%$ and the rest respondents are $>50$ years old and 21 - 30 years old. Those having working experience of 10 - 15 years are 35 respondents or $34 \%$ and 15 - 20 years are 25 respondents or $24 \%$ and the rest respondents are having working experience of $5-10$ years, $>20$ years and <5 years. Respondents' education level is dominated by graduation from post graduate of 64 respondents or $63 \%$ and bachelor degree of 38 respondents or $37 \%$.

\subsection{Validity test}

Validity test is used to assess the extent of the accuracy and accuracy of a measuring instrument in carrying out its size function. In this validity test, data $r$ tables are needed as parameters of the adequacy of the values and validity requirements. With a significance level of $5 \%$, the $\mathrm{r}$ table value of 0.1946 was obtained.

Questionnaire of this research uses Likert scale with 5 assessment levels with score 5 for very good/absolutely agree and score 1 for very bad/absolutely disagree. By using Microsoft Excel software, preliminary testing of the questionnaire data for the number of research samples was 102 respondents, the smallest r-count value was 0.6442 and the highest was 0.7886 . With an r-table value of 0.1946 , the validity test results using Microsoft Excel software on each question have r-count values greater than r-tables, so it is concluded that all questions in the questionnaire answered by the respondents were Valid. The questions with the lowest $r$-count value are for the Stages of Evaluation variable questions and the highest $r$-count is for the Material variable questions.

\subsection{Reliability test}

Reliability testing with SmartPLS is done by comparing the Cronbach's alpha value and the Composite Reliability value of each variable with a critical point value greater than 0.7 .

Cronbach's Alpha and Composite Reliability results are displayed in a table according to SmartPLS 3.0 output as follows:

Table 1: Cronbach's Alpha and Reliability Test Results with Smartpls

\begin{tabular}{lll}
\hline Variabel & Cronbach's Alpha & Composite Reliability \\
\hline Project Characteristic & 0.837 & 0.885 \\
Ability of Contractor & 0.843 & 0.882 \\
Application of New Technology & 0.852 & 0.910 \\
Tender Process & 0.860 & 0.914 \\
\hline
\end{tabular}

Based on the table above shows that the value of Cronbach's Alpha and Composite Reliability for all variables is greater than 0.7 , so it can be said that all latent variables are reliable.

\subsection{Outer model evaluation}

Evaluation of the measurement model is used to measure the loading factor, validity and reliability and Cronbach's alpha. This measurement model evaluation uses SmartPLS 3.0 software. The loading factor is the value used to test the validity of research indicators based on the result of questionnaires.

To see how much the contribution of indicators in explaining the construct variables can be seen by calculating the loading factor. The loading factor value required is a minimum of 0.7 , so if in the loading factor calculation the resulting value is less than the loading factor value 0.7 , then it must be removed from the test model and then an estimate is made to re-estimate the model.

From the estimation of this model, there is one indicator that has a loading factor value of less than 0.7 which must be removed from the test model and then re-estimated on the model, namely the Environmental Safety Project. 
After re-estimation, then checking the value of cross loading, the cross loading value must be greater than the correlation value. Indicators which not meet to the requirement above, must deleted from model and shall be re-estimate.

From the estimation of this model, there are two indicators that have a smaller value than the correlation, then the indicator must be removed from the test model and then re-estimated on the model, Quota Package and Capital.

The next check is convergent validity by looking at the results of the convergent validity values by using the AVE value. The recommended minimum AVE value is 0.5 . The reliability test results show that all constructs in the model have good reliability values. This can be seen from the AVE value in all constructs that have a value greater than 0.5 .

Table 2: Value of Average Variance Extracted (AVE)

\begin{tabular}{ll}
\hline Variable & AVE \\
\hline Ability of Contractor & 0.707 \\
Project Characteristic & 0.662 \\
Application of New Technology & 0.771 \\
Tender Process & 0.780 \\
\hline
\end{tabular}

Composite reliability and Cronbach's alpha measurement instruments were carried out to conduct construct reliability tests on the model. From the estimation results of the models that have been done, obtained composite reliability values above 0.7 and Cronbach's alpha above 0.6 , so that all constructs in the tested model have good reliability.

\subsection{Influence of $\mathrm{f} 2$ and $\mathrm{q} 2$ predictive relevance}

Measure of influence indicated by the value $\left(\mathrm{f}^{2}\right)$, carried out to measure how much influence each variable has at the structural level. If the value $\left(\mathrm{f}^{2}\right)$ is equal to 0.02 , it has a small effect, equals 0.15 , has an intermediate influence and is equal to 0.35 , then has a large effect.

Table 3: The Amount of Influence F2

\begin{tabular}{|c|c|c|}
\hline Relation & f Square & Result \\
\hline Ability of Contactor> Tender Process & 0,001 & Small \\
\hline Project Characteristic $>$ Tender Process & 0,298 & Medium \\
\hline Application of New Technology $>$ Tender Process & 0,001 & Small \\
\hline Project Characteristic > Ability of Contractor & 0,317 & Medium \\
\hline Application of New Technology $>$ Project Characteristic & 0,699 & Large \\
\hline Application of New Technology > Ability of Contractor & 0,875 & Large \\
\hline
\end{tabular}

Table 4: $\mathrm{R}^{2}$ Dan $\mathrm{Q}^{2}$ Predictive Relevance

\begin{tabular}{lll}
\hline Relation & R-Square & $1-$ R-Square \\
\hline Project Characteristic & 0,411 & 0,589 \\
Ability of Contractor & 0,760 & 0,240 \\
Tender Process & 0,450 & 0,550 \\
\hline
\end{tabular}

The estimation results of the model estimation as shown in the table above, show that the value of $\mathrm{Q}^{2}$ (Q-Square Predictive Relevance) obtained in all four variables is 0.078 , which means the value is greater than 0 (zero), so the measurement model is concluded to have a predictive relevance value.

\subsection{Inner model evaluation}

Evaluation of the structural model on PLS-SEM is done by performing the R-Squared ( $\left.\mathrm{R}^{2}\right)$ test for the dependent variable and the path coefficient value for the independent variable which is then assessed for its significance based on the t-statistic value of each path. The structural model of this research can be seen in the following figure:

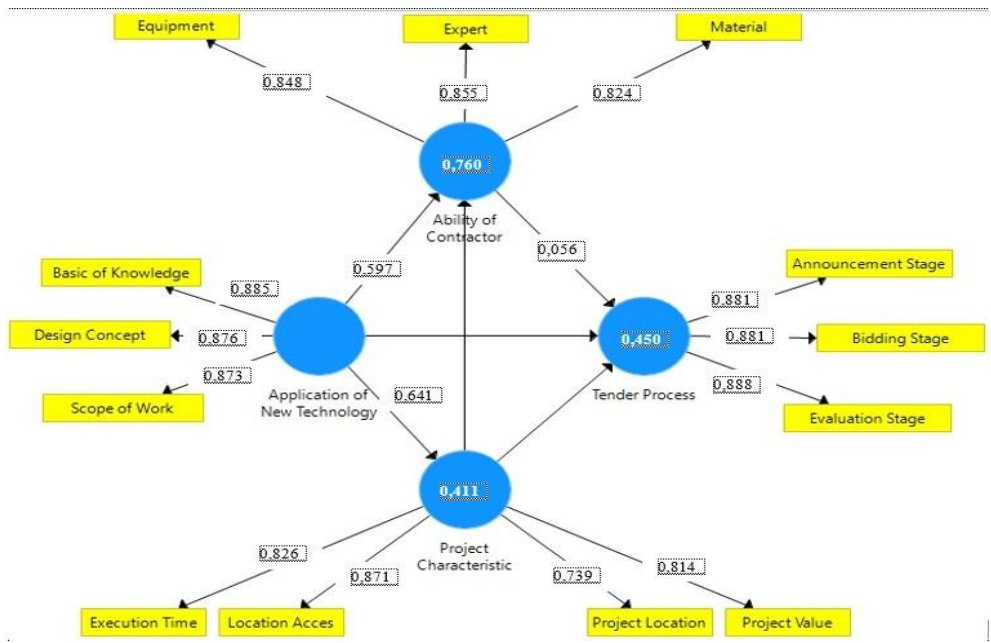

Fig. 2: Standard Measurement Model for Test Samples.

From figure 2, the equation obtained from the model measurement for all sample data is as follows:

1) $\mathrm{R}^{2}$ value of the Tender Process is 0.450 , meaning that the Tender Process is related to the Capability of the Contractor, the Characteristics of the Project and the Application of New Technology by 45\%, while the rest is determined by other factors that are not appropriate in this study. 0.06 with positive direction. This proves the relationship in the same direction found. If the Contract 
Capability increases by 1 level, the Tender Process will increase to 0.444 and reverse. Likewise, the Characteristics and New Technology Application Project which has a path coefficient of 0.605 and 0.035 with a positive Direction, thus proving a relationship in the same Direction was found. If the Project Characteristics and Application of New Technologies increase by 1 level, the Tender Process will increase to 0.605 and 0.035 and otherwise.

2) R2 value of Contractor's Ability is 0.760 , meaning that the Ability of a Contractor is influenced by Project Characteristics and Application of New Technology by $76 \%$, while the rest is influenced by other factors not examined in this study. Project Characteristics and Application of New Technology has a path coefficient of 0.359 and 0.597 with a positive direction. This proves that relationships in the same direction are found. If the Project Characteristics and Application of New Technology increase by 1 level, the Contractor's Capability will increase to 0.359 and 0.597 and otherwise.

3) The R2 value of the Project Characteristics is 0.411, meaning that the Project Characteristics are influenced by the Application of New Technology by $41.1 \%$, while the rest is influenced by other factors not examined in this study and the path coefficient for the Application of the New Technology by 0.641 with a positive direction proving a relationship in the direction the same one. If the Application of New Technology increases by 1 level, the Project Characteristics will increase to 0.641 and otherwise.

\subsection{Hypothesis testing}

1) Partial hypothesis testing

Testing this hypothesis to find out whether the research hypothesis is accepted or rejected. The hypothesis accepts values greater than 0.1 and $\mathrm{P}$ values greater than 0.05 .

The results of the partial hypothesis test using Sem-PLS, the results obtained that the hypothesis that can be accepted because the significance value is hypotheses 1 and 3 that is the influence of the ability of Contractors and the Application of New Technology to the Tender Process.

Table 5: Path Coefficient, T-Count, Partial Hypothesis

\begin{tabular}{|c|c|c|c|c|}
\hline & Path Coefficient & $\mathrm{t}$-Count & Significance & Result \\
\hline Ability of Contractor> Tender Process & 0,056 & 0,321 & 0,000 & H1 accepted \\
\hline Project Characteristic $>$ Tender Process & 0,605 & 6,132 & 0,076 & $\mathrm{H} 2$ rejected \\
\hline Application of New Technology> Tender Process & 0,035 & 0,217 & 0,001 & H3 accepted \\
\hline
\end{tabular}

Having obtained the analysis of the three models above, can be analyzed more slowly by measuring the direct relationship of variables with other variables so that a significant effect is known. This measurement is carried out in order to see how much influence between these variables, so that stakeholders can get more complete information about the factors that influence the success of the tender process which is used as a reference in making final conclusions.

Table 6: Path Coefficient, T-Count and Other Variable

\begin{tabular}{|c|c|c|c|c|}
\hline & Path Coefficient & t-Count & Significance & Result \\
\hline Characteristic Project> Ability of Contractor & 0,359 & 4,561 & 0,000 & Significance \\
\hline Application of New Technology > Characteristic Project & 0,641 & 9,814 & 0,000 & Significance \\
\hline Application of New Technology > Ability of Contractor & 0,597 & 7,685 & 0,000 & Significance \\
\hline
\end{tabular}

2) Mediation hypothesis testing

Mediation test is one of the other hypothesis tests conducted in order to see the significance of the relationship between variables, namely the predictor variable on the criterion variable.

The test results show that the estimation of the measurement model is able to prove the significant influence of the Project Characteristics as a mediating variable between the Application of New Technology and the Capability of the Contractor and the Characteristics of the Application of the New Technology and the Tender Process.

Table 7: Mediation Variable Measurement Results

\begin{tabular}{|c|c|c|c|c|}
\hline & Path Coefficient & $\mathrm{t}-$ Count & Significance & Result \\
\hline Application of New Technology $>$ Project Characteristic $>$ Ability of Contractor & 0,231 & 4,131 & 0,000 & $\begin{array}{l}\text { Signif- } \\
\text { icance }\end{array}$ \\
\hline Application of New Technology $>$ Project Characteristic $>$ Tender Process & 0,389 & 5,219 & 0,000 & $\begin{array}{l}\text { Signif- } \\
\text { icance } \\
\text { Not }\end{array}$ \\
\hline Project Characteristic $>$ Ability of Contractor $>$ Tender Process & 0,015 & 0,295 & 0,768 & $\begin{array}{l}\text { Signif- } \\
\text { icance } \\
\text { Not }\end{array}$ \\
\hline Application of New Technology $>$ Characteristic Project $>$ Ability of Contractor $>$ Tender Process & 0,011 & 0,289 & 0,773 & $\begin{array}{l}\text { Signif- } \\
\text { icance } \\
\text { Not }\end{array}$ \\
\hline Application of New Technology >Ability of Contractor >Tender Process & 0,034 & 0,294 & 0,769 & $\begin{array}{l}\text { Signif- } \\
\text { icance }\end{array}$ \\
\hline
\end{tabular}

3) Simultaneous hypothesis test

This hypothesis is to determine the effect of the independent variables simultaneously on the dependent variable, by comparing the calculated $\mathrm{F}$ value with the $\mathrm{F}$ table value, using the following formula:

$\mathrm{F}$ count $=\frac{(\mathrm{n}-\mathrm{k}-) \mathrm{R}^{2}}{\mathrm{~K}\left(1-\mathrm{R}^{2}\right)}$

Particulars:

$\mathrm{n}=$ total sample

$\mathrm{k}=$ total independent variable

$\mathrm{R}^{2}=\mathrm{r}$ square 
Whereas the F table is obtained from the table using the DF1 and DF2 instruments with the following formulation: $\mathrm{DF} 1=$ total dependent variable

$\mathrm{DF} 2=\mathrm{n}-\mathrm{k}-1$

By using the formula above, we obtain $\mathrm{F}$ count and $\mathrm{F}$ table as follows:

Table 8: Simultaneous Hypothesis Testing Model

\begin{tabular}{|c|c|c|c|}
\hline & F count & F table & Result \\
\hline Characteristic Project, Ability of Contractor and Application of New Technology $>$ Tender Process & 49 & 2.70 & H accepted \\
\hline
\end{tabular}

Based on the table above, it can be concluded that the simultaneous hypothesis between variable project characteristics, the ability of contractors and the application of new technologies has a significant influence on the tender process.

\subsection{Discussion and implication of research}

Based on the results of testing the hypotheses in the interaction model for all sample data, it can be concluded that in this interaction model, Project Characteristics have the most significant influence on the Tender Process because it involves the project location, site access and project implementation time.

Project location is the most influential factor because not all contractors are able to mobilize their resources when project locations depend on remote and difficult locations, because technology implementation activities are carried out in remote areas. This then directly affects access to the location and time of project implementation.

The Contractor's Capability is the second variable which also influences the Tender Process which is influenced by sequential factors, namely: Capital, Equipment, Expert, Material.

The Capital and Equipment Factor is the most influential because it is the most important resource for contractors to participate in tenders. Capital and equipment become a strength that shows that the contractor can carry out well.

For the Application of New Technology, the influence is ranked third for the contractor to determine whether to continue the Tender Process or stop. The application of new technology is influenced by factors such as: Basic Knowledge, Design Concepts and Scope of Work.

Basic knowledge of the technology to be applied becomes very important because having good knowledge of the technology makes it easy to understand the design concepts of technology which are then elaborated on the scope of work. Mastery of basic knowledge becomes capital for the contractor to be able to provide feed back by providing input in the form of engineering and development when at the time of implementation found obstacles in the application of technology.

\section{Conclusion and Suggestion}

\subsection{Conclusion}

The results of the analysis and discussion of the data, the authors obtain conclusions that can be drawn from research on the factors that affect the contractor's participation in the tender process of construction service projects in the Ministry of Public Work and Public Housing as follows:

1) There is a significant influence between the ability of the Contractor to the contractor not continuing the Tender Process with the factors that affect it in sequence, namely Equipment, Materials and Experts.

2) There is no significant effect between the Project Characteristics on the contractor not continuing the Tender Process with the factors that affect it sequentially namely the Project Location, Access Location, Time of Implementation and Project Value.

3) There is a significant influence between the Application of New Technology to the contractor not continuing the Tender Process with factors that affect it sequentially namely Design Concepts, Scope of Work and Basic Knowledge.

4) Simultaneously, the hypotheses between Project Characteristics, Contractor Capability and the Application of New Technology have a significant influence on the Tender Process which is marked by the results of F arithmetic and F tables received so that the hypothesis can be proven in the analysis of the model. This shows that although in the hypothetical variable the Project Characteristics is rejected, the variable still has significance in the decision making by the contractor when deciding whether to continue or stop participating in the tender process.

\subsection{Suggestion}

Based on the results of research that has been done, there are several suggestions, namely:

1) Future research is expected to conduct research on all technology implementation projects, not only in the Research and Development Center for Policy and Application Technology - Research and Development Agency - Ministry of Public Work and Public Housing, but can be carried out on all technology implementation projects, so that research results are more comprehensive.

2) Future studies are expected to be able to carry out testing with more developed models, so that the results of the study can better give a better picture

\section{References}

[1] Abidin. Said Zainal. 2012. Kebijakan Publik. Jakarta: Salemba Humanika.

[2] Adrian. Sutedi. 2012. Good Corporate Governance. Jakarta: Sinar Grafika.

[3] Alfian Malik. 2010. Pengantar Bisnis Jasa Pelaksana Konstruksi. Yogyakarta: Andi Offset.

[4] Andrianto. Nico. 2007. Transparasi dan Akuntabilitas Publik melalui e-Government. Malang: Bayumedia Publishing.

[5] Arrowsmith S. 2004. Public Procurement: An Appraisal of the UNCITRAL Model Law as a Global Standard. International Law \& COMPQuarterly. https://doi.org/10.1093/iclq/53.1.17.

[6] Bahagia Nur. 2011. Senarai Pengadaan Barang/Jasa Pemerintah: Site. Pengadaan Publik dan Cakupannya. Jakarta: Jurnal Pengadaan LKPP. 
[7] Bambang Prasetyo dan Lina Miftahul Jannah. 2010. Metode Penelitian Kuantitatif: Teori dan Aplikasi. Jakarta: Raja Grafindo Persada.

[8] Benny Kurniawan. 2012. Metodologi Penelitian. Tangerang Selatan: Hak Cipta.

[9] Brandon-Jones. A. \& Carey. S. (2011). The Impact of User-Perceived e-Procurement Quality on System and Contract Compliance. International Journal of Operations \& Production Management. https://doi.org/10.1108/01443571111111928.

[10] Budi Susetyo and Tin Budi Utami. 2017. Bidding Cost Evaluation with Fuzzy Methods on Building Project in Jakarta. AIP Conference Proceedings 1903, 070004 (2017); https://doi.org/10.1063/1.5011573

[11] Chow H.K.H., Choy K.L., Lee W.B. and Chan, F.T.S., 2005. Design of knowledge-based logistics strategy system. Experts system with Applications. https://doi.org/10.1016/j.eswa.2005.04.001

[12] Christopher \& Schooner. 2007. Incrementalism: Reoding the Impediemnts to a Global Public Procurement Market. Journal of International Law.

[13] Dalkey, N. C. 1972. The Delphi method: An experimental study of group opinion. In N. C. Dalkey, D. L. Rourke, R. Lewis, \& D. Snyder (Eds.). Studies in the quality of life: Delphi and decision-making (pp. 13-54). Lexington, MA: Lexington Books.

[14] Dwi. Bagas. dkk. 2017. Pengaruh Competitive Bidding pada Pekerjaan Konstruksi terhadap Penawaran Pemenang Tender dalam e-Procurement LPSE PT. PLN (PERSERO). Purwokerto.

[15] Egbu C. Vines M. and Tookey J. (2004). The Role of Knowledge Management in e-Procurement Initiatives for Construction Organisations. ARCOM Proceedings Twentieth Annual Conference 2004 (Khosrowshami.F. editor) Volume 1. 661 - 67

[16] Ghozali. Imam. 2014. Structural Equation Modeling. Metode Alternatif dengan Partial Least Square (PLS). Edisi 4. Semarang: Badan Penerbit Universitas Diponegoro.

[17] Gene Rowe. George Wright. 1999. The Delphi technique as a forecasting tool: issues and analysis. International Journal of Forecasting. Volume 15, Issue 4, October 1999, Pages 353-375. https://doi.org/10.1016/S0169-2070(99)00018-7.

[18] Guritno. 1992. Kamus Ekonomi Bisnis Perbankan Inggris - Indonesia. Gadjahmada University Press: Yogyakarta. Hal 24.

[19] Gray. Clive. dkk. 1993. Pengantar Evaluasi Proyek. Jakarta: Penerbit Gramedia Pustaka Utama. Jakarta. (Penyunting Mia 2009).

[20] Harold A. Linstone, Murray Turoff. 1975. The Delphi method: techniques and applications. Addison-Wesley Pub. Co.

[21] Hendrawan. Hendra. 2018. Faktor yang Mempengaruhi Keberhasilan Penerapan Teknologi Bidang Jalan dengan Kontrak Rancang Bangun. Bandung: Media komunikasi Teknik Sipil. https://doi.org/10.14710/mkts.v24i1.18376.

[22] Handoko, T. Hani. 2010. Manajemen Personalia \& Sumber Daya Manusia. BPFE-Yogyakarta.

[23] Hanke, J. E., and D.W. Wichern. 2005. Business Forecasting. 8th ed, Pearson Prentice Hall.

[24] Helmer O. 1983. Looking Forward: A Guide to Futures Research Sage Publications. Beverly Hills.

[25] Henry Simamora. 2000. Manajemen Pemasaran Internasional (jilid 1). Hal. 411. Jakarta: Salemba Empat.

[26] Iman Soeharto. 1999. Manajemen Proyek: Dari Konseptual sampai Operasional. Hal 22. Jakarta: Penerbit Erlangga.

[27] Kalakota. Ravi and Marcia Robinson. 2001. e-Business 2.0: Roadmap for Success. Addison Wesley. Longman Inc.Cambridge. Massachusse.

[28] Keputusan Dewan Lembaga Pengembangan Jasa Konstruksi Nasional Nomor: 75/KPTS/LPJK/D/X/2002 tentang Pedoman Sertifikasi dan Registrasi Badan Usaha Jasa Pelaksana Konstruksi Nasional.

[29] Ketut. Suditpa. 2016. Analisis Faktor yang Mempengaruhi Kontraktor dalam Pengambilan Keputusan pada Pelelangan Pemerintah dengan Sistem e-Procurement. Bali: Universitas Udayana.

[30] LPJK. 2008. Jasa Kontruksi. Jakarta: Lembaga Pengembangan Jasa Kontruksi.

[31] Malik. Alfian. 2010. Pengantar Bisnis Jasa Pelaksana Konstruksi. Yogayakrta: Andi Offset. (Penyunting Zaenal Arifin 2012).

[32] Mawardi Amin. 2017. Development of Cost Estimation Model for Residential Building. International Journal of Civil and Structural Engineering Research ISSN 2348-7607 (Online) Vol. 5, Issue 1, pp: (1-4), Month: April - September 2017, Available at: www.researchpublish.com.

[33] Morledge, R. And Adnan, H., 2003. Application of Delphi methods to research on critical success factors in joint venture projects in Malaysia. In: Proceedings of the second international conference on construction in the 21 st century: sustainability and innovation in management and technology, Hong Kong.

[34] Nadisa. Mayun. dkk. 2014. Analisis Faktor-faktor yang Mempengaruhi Gagal Lelang Pengadaan Barang dan Jasa Pemerintah secara Elektronik (e-Procurement) di Kabupaten Badung. Bali: Jurnal Spektran.

[35] Nightisaba, Ita Akyuna. 2009. Jurnal Siasat Bisnis. Vol 13 No 2. Persepsi Pengguna Layanan Pengadaan Barang dan Jasa Pada Pemerintah Kota Yogyakarta Terhadap Implementasi Sistem e-Procurement. Terdapat pada http://journal.uii.a.id/index.php/JSB/article/view/2018/1772.

[36] Noferi. Sayfran. 2017. Analisis Faktor Penyebab Calon Penyedia Jasa Melakukan Pendaftaran Lelang Tetapi Tidak Melanjutkan Memasukan Dokumen Penawaran Pada Pengadaan Jasa Konstruksi Pemerintah. Bandung: Jurnal Infrastruktur. https://doi.org/10.20885/jsb.vol13.iss2.art3.

[37] Peraturan Presiden Republik Indonesia Nomor 16 Tahun 2018 tentang Pengadaan Barang dan Jasa Pemerintah.

[38] Peraturan Menteri Pekerjaan Umum Nomor 07/PRT/M/2012 tentang Penyelenggaraan Penelitian dan Pengembangan.

[39] Peraturan Lembaga Jasa Konstruksi Nomor: 11a Tahun 2008 tentang Registrasi Usaha Jasa Konstruksi.

[40] Philip Kotler dan Kevin Lane Keller. 2007. Manajemen Pemasaran. Jilid II. Ed. 12. Terj. Benjamin Molan. Jakarta: Prenhallindo. (Penyunting Saliq NC 2017).

[41] Pujawan. I. N. 2005. Supply Chain Management (1stEdition ed.). Indonesia:Gunawidya.

[42] Respawan. Made. dkk. 2017. Analisis Faktor Yang Mempengaruhi Partisipasi dan Nilai Penawaran Peserta Lelang Elektronik (e-Procurement) Jasa Konstruksi di Kabupaten Buleleng. Bali: Jurnal Spektran. https://doi.org/10.24843/SPEKTRAN.2017.v05.i01.p01.

[43] Ricky W. Griffin. Ronald J. Ebert. 2006. Bisnis (Terjemahan Sita Wardhani). Surabaya: Erlangga. (Penyunting Saliq NC 2017).

[44] Simon R. Croom and Alistair Brandon-Jones. 2005. Key Issues in e-Procurement: Procurement Implementation and Operation in the Public Sector. Journal of Public Procurement. Volume 5. Issue 3. 367-387. https://doi.org/10.1108/JOPP-05-03-2005-B004.

[45] Skutsch, Margaret Hall, Diana. 1973. Delphi: Potential uses in educational planning. Project Sims u-School: Chicago Component.

[46] Sudaryono. 2017. Metodologi Penelitian. Edisi 1. Jakarta: Rajawali Pers.

[47] Sugiyono. 2017. Metode Penelitian Kuantitatif. Kualitatif. dan R\&D. Cet. Ke-26. Bandung: Alfabeta.

[48] Panayiotou. N. A. Gayialis. S. P. \& Tatsiopoulos. I. P. 2004. An e-Procurement System for Governmental Purchasing. International Journal of Production Economics. Volume 90. 79-102. https://doi.org/10.1016/S0925-5273(03)00103-8.

[49] Teo. T. S. Lin. S. \& Lai. K.-h. 2009. Adopters and non-Adopters of e-Procurement in Singapore: An Empirical Study. Volume 37. $972-987$ Omega. https://doi.org/10.1016/j.omega.2008.11.001.

[50] Tim Peneliti. 2017. Dokumen Output Replikasi Perdana Teknologi Asbuton. Surabaya: Balai Penelitian dan Pengembangan Penerapan Teknologi Jalan dan Jembatan.

[51] Tim Peneliti. 2017. Laporan Akhir Penerapan Teknologi di KSPN Danau Toba. Yogyakarta: Balai Penelitian dan Pengembangan Penerapan Teknologi Permukiman.

[52] Undang-Undang Nomor 2 Tahun 2017 tentang Jasa Kontruksi.

[53] Whellwright, S. C., and S. Makridakis. 1980. Forecasting Methods for management, 3th ed.

[54] William J. Stanton. 1996. Prinsip Pemasaran. Jilid 1 Edisi VII (Terjemahan Yohanes Lamarto). Jakarta: Erlangga. (Penyunting Saliq NC 2017).

[55] Wulfram I. Ervianto: 2002. Proyek Kontruksi. Malang. Halaman 3. (Penyunting D Kamelia 2017). 